\title{
Hardening the budget constraint: Institutional reform in the financial management of Hungarian local governments
}

\begin{abstract}
TAMÁS VASVÁRI*
University of Pécs, Faculty of Business and Economics, Rákóczi út 80, Pécs, H-7622, Hungary

Received: August 12, 2018 • Revised manuscript received: November 8, 2018 Accepted: December 13, 2018

(c) 2020 The Author(s)

ABSTRACT

Kornai (2014) described the problems of municipal indebtedness in Hungary and analysed the process of bailout carried out between 2011 and 2014. In the same period, the central government also reformed the local government system, which included serious limitations of their financial independence. This study re-examines the state of the soft budget constraint (SBC) of Hungarian local governments. To start, the general theoretical framework of SBC is introduced. Then, the budget constraint on the Hungarian local governments before the bailout is described briefly, followed by an assessment of the corresponding measures which were expected to offset the negative messages of the completed bailout and to harden the budget constraint. The study concludes that the central government decided to harden the budget constraint through the introduction of new hierarchical mechanisms, while the development of fiscal discipline stopped. On the one hand, this resulted in the consolidation of municipal budgets, but on the other, it was accompanied by a serious limitation of local autonomy, projects and borrowing in general, while the central government employs specific administrative tools to show favour to some settlements according to its (political) interests.
\end{abstract}

\section{KEYWORDS}

local government, soft budget constraint, bailout, fiscal discipline

JEL CLASSIFICATION INDICES

$\mathrm{H} 60, \mathrm{H} 7, \mathrm{H} 74$

*Corresponding author. E-mail: vasvari.tamas@ktk.pte.hu 


\section{INTRODUCTION}

The financial management of local governments in Hungary was ripe for a large-scale reform by the beginning of the 2010s. Renowned specialists and researchers have often pointed out that the local government system is under significant stress. Its perhaps most conspicuous sign was the very fast growth of municipal debt. The reasons were diverse. According to Vigvári (2010), central politics considered local governments to be 'conflict containers' up until 2010 and tried to delegate all issues involving political risks to these lower levels. The relief valve of the overpressure brought about by the simultaneously appearing operating deficit and the expansion drive was the high degree of freedom of local governments on money and capital markets even by the Western European standards. This delayed the adjustment of budgetary expenditures to revenues and real capabilities. In addition, due to the weaknesses of the institutional framework, fundraising from external sources by local governments was controlled only by the willingness of the banks to lend and take risks. The fundamentals of fiscal discipline were missing, including the fact that local governments and later also the banks believed (in spite of the relevant clear legal rule) that the central government will never release the hands of large local governments. And so it happened: simultaneously with the transformation of the statutory foundations of the sector, the central government set about assuming municipal debt and simply deleting the memento of the guilty past. Apparently, there were only winners in the process: in the short term, the benefactor government saved the troubled local governments and, starting from a clean slate, the local governments can continue performing local public affairs. However, this simplified narrative conceals a number of effects and consequences. The municipal debt consolidation is undoubtedly the strongest indication in the past 20 years of the fact that the budget constraint of local governments is soft: the expectation of being bailed out may determine the decisions of local governments in the long term and may encourage them to continue overspending. The central government had to act in order to harden the budget constraint and to consolidate the financial management of local governments in order to avoid the reproduction of outstanding debt. The central government planned to achieve this goal by introducing administrative controls into the financial management of the local governments instead of promoting fiscal discipline and strengthening the corresponding institutions (e.g. the municipal debt settlement procedure).

This study examines whether the legislative measures achieved the objectives set, together with further consequences of the reform, which has not been analysed in detail in the literature. Introducing the concept of soft budget constraint (SBC) into the analysis could provide new, additional insight in the operation of local governments, which remained unexplored before. The Hungarian example could also deliver valuable experiences to examine the changes in the local government systems at international level.

The first Section of the paper briefly reviews the literature on SBCs, especially in respect of the local government system. The pillars of the new local government system are shown in the second Section, which is followed by formulating the hypotheses on the financial management of the local governments. In Section 4, the hypotheses are verified, then conclusions are drawn.

\section{THE SOFT BUDGET CONSTRAINT}

The idea of SBC was formulated for the first time by János Kornai in a 1978 paper published in Hungarian ('Reproduction of Shortage'), then in his book entitled 'Economics of Shortage' (1980). 
In socialist systems, as Kornai argued, state-owned enterprises are not afraid of bankruptcy or liquidation even in the event of loss-making operation. Their managers know that they will survive difficulties as a result of help from the central government. Kornai et al. (2003) and Kornai (2014) structure and summarise the problem of SBCs and the research in 25 and 35 years, respectively, since the ideas were formulated, which significantly widened the application of the conceptual framework of the SBC: today the bailout of privately owned companies (e.g. declining sectors) or certain operators in the financial sector no longer staggers anyone, especially in the knowledge of the events in the recent financial crisis. At the level of the national economy, bailing out non-profit organisations (e.g. hospitals, schools, universities) and debtridden, insolvent local governments is common. This study focuses on the latter phenomenon, for which it is essential to describe the theory of the SBC in more detail.

In general, we can talk about the phenomenon of SBCs if 'the behaviour of every organization concerned is affected by the expectation that it will be bailed out if it gets into serious financial trouble' (Kornai 2014: 27). There are organisations subject to budget constraints, which must cover their expenses from their initial assets and revenues. In the present case, these organisations are local governments. The difference between revenues and expenses (deficit) may be covered by a 'support organisation', in the present case, the central government. The phenomenon of SBC arises when the financial decisions of local governments are determined by the expectation that they will be bailed out if they get into serious financial trouble.

In the case of local governments, the hardness of the budget constraint is related to the extent of fiscal decentralisation. In the course of fiscal decentralisation, the performance of public service tasks is divided between the central government and the subnational levels; in accordance with the principle of subsidiarity, decisions move closer to residents, and local needs become easier to meet, while locally elected representatives and bodies become more accountable. However, in addition to its advantages, this division of tasks also includes challenges. The principle of economies of scale may be infringed, while it may be more difficult for the central government to look after its stabilisation tasks, and the performance of subnational levels of government may pose a risk to government deficit and debt; the latter are critical especially if such performance indicators are set for the entire national economy, as the Maastricht criteria (Dafflon 2010). Thus, decisions made by the municipal leaders may be significantly influenced by the expansion drive, i.e. to be able to provide as good public services and as many projects to their residents as possible; this encourages them to overspend until they hit barriers. Kornai (2014) explains that in some of the cases cautiousness and self-control may also be limiting factors, but in most cases, restrictions come from outside, e.g. withdrawal of market operators and closing of credit sources, while they may also include legislation or administrative tools restricting expenditures or borrowing. In the decentralised countries, the reason for overspending by local governments is that they are more inclined to assign higher priority to their own local interests than to the interests of the country, the entire community. Importantly, Inman (2003) already raised the point that passing through the costs can be interpreted not only in space, but also in time: if current expenditures are covered by credit, different generations enjoy the benefits and will bear the burdens.

In the case of local governments, we can talk about serious financial trouble when the state of insolvency is permanent and they have cumulative (operating) deficits for several years, are unable to make instalment payments or just cannot get another loan, because they have lost their creditworthiness. Regarding the frequency of financial trouble, bailouts can take place once, repeatedly or regularly. Bailout may mean the cancellation of tax arrears, the easement of the terms of repayment, the cancellation/assumption of debt or even the provision of fresh loans. 
Rodden et al. (2003) showed the mechanism of the SBC as a three-step sequential game. The central government can be of two types: it supports bailout or distances itself from it. Local governments individually evaluate the probability of commitment by the central government. In the first step, the central government sets a framework for the financing and financial management of local governments and also declares that there will be no bailout and emphasises the responsibility of local governments for their own financial management. In the second step, local governments analyse the authenticity of the declarations and commitment of the central government. Based on this, they may decide to manage their finances within the given framework and in accordance with the specific rules; in this case, the game is over. If, however, they decide to overspend, they may request for additional support to be provided, or their existing debts be assumed. In the final step, the central government decides on the basis of the costs and consequences whether to bail out the local government or distances itself from any bailout.

The key question is motivation: what can encourage the central government to bail out a local government? The SBC is a question of commitment in the relationship between local governments and the central government: if a local government gets into financial trouble, will the central government provide it additional support or will it let the local government eliminate the problem itself? It makes the decision more difficult as the central government often does not have sufficient information about whether the local government managed its finances well and got into financial trouble through no fault of its own or it results from deliberate overspending. The bailout of local governments can be explained by a number of reasons: the bankruptcy of individual local governments may involve significant negative externalities in the performance of public service tasks and in the employment of public service employees. At the same time, the insolvency of a large local government may also affect the credit rating of the country, while the performance of the local governments may worsen consolidated state budget indicators (deficit and debt). It may further strengthen the motivation of the central government for a bailout if the statutory framework does not protect private property and if credit agreements are not enforceable: in this case, the central government may compensate creditors with a bailout. If financial trouble appears in very large numbers, due to the intensification of social tensions, the political forces may lose their popularity at local and/or central government level: thus, a bailout may be justified by political survival and vote maximisation (Kornai 2014). Robinson - Torvik (2009) apply the premise that the SBC is not only one of the effects of fiscal decentralisation that politicians would get rid of (if they were credibly able to do so), but the central government consciously aims to maintain the softness of the budget constraint, because the SBC is suitable for building political clientelism: the recurrence of getting into trouble and bailout tightens the patron-client relationship. This is confirmed by Fink - Stratman's (2009) research, which shows in an example from Germany that budget constraints are not uniformly soft for every local government: the softness of the budget constraint depends on the bargaining power of individual local governments. As a result, influential local governments have a higher deficit and do not follow a tight fiscal policy. ${ }^{1}$ Wildasin (1997) explains that the probability of bailouts increases in proportion to the size of municipalities, i.e. the budget constraints on smaller local governments are harder. The reason for this is that the external effects of larger local governments going bankrupt are higher and may significantly

\footnotetext{
${ }^{1}$ Goodspeed's (2002) conclusions go further: for the central government, it would be worth bailing out opposition local governments in order to get votes and become re-elected. In this respect, Robinson - Torvik (2009) draws the conclusion that it is more rewarding for decision-makers to embrace bad projects, because this way they can provide funds to their supporters through a bailout. This is not true in the case of good projects, 'everyone can back them'.
} 
exceed the costs of a bailout ('too big to fail'). Therefore, Wildasin comes to the conclusion that the reason for SBCs is not excessive decentralisation, but its low level: it would be desirable to break up larger municipal units into smaller ones in order to harden the budget constraint.

We could see that the SBC prevalent in the financial management of local governments is a very challenging feature arising from fiscal decentralisation, the main disadvantage of which is that it encourages wanton spending at the expense of others. Local governments may provide public services and launch projects irresponsibly, without those being covered by their budgets. If the expectation of the local government for a bailout is strong enough, it may lead to significant overspending, which makes it impossible to refuse a bailout. In an extreme case, a moral hazard also appears: if the local government knows that it can certainly count on being rescued by the state, it is not worth of making any effort to avoid losses or to repay a loan; in fact, it may even keep on increasing its expenditures (Kornai 1993). In addition, the SBC also affects the preference of decision-makers: the operation and development of the organisation may be relegated to the background, while the establishment of relations with potential bailout providers may receive more attention. At the same time, Besfamille - Lockwood (2007) explain that by contrast a hard budget constraint may cause a setback in projects; moreover, the local governments have to make a disproportionate sacrifice to filter out bad projects, which leads to inefficiency.

What means can be used to decrease or even eliminate the effects of the SBC? According to Rodden - Eskeland's (2003) approach, a SBC develops if the central government proves to be too vulnerable to the financial processes or perhaps crisis arising at the municipal level, and at the same time it is too weak or deliberately does not take action to prevent overspending by administrative and regulatory tools. Besfamille - Lockwood (2007) see two ways to eliminate the SBC: in the topdown approach, the central government establishes a hard budget constraint by hierarchical mechanisms'. By contrast, according to the bottom-up approach ('unconstrained decentralization'), fiscal discipline emerges as a result of (self-) assessment by the local governments and the restrictive power of market mechanisms harden the budget constraint; to this end, the central government must successfully distance itself from the local government system and, at the same time, must also reduce its internal vulnerability (Fig. 1). These two methods are presented in detail.

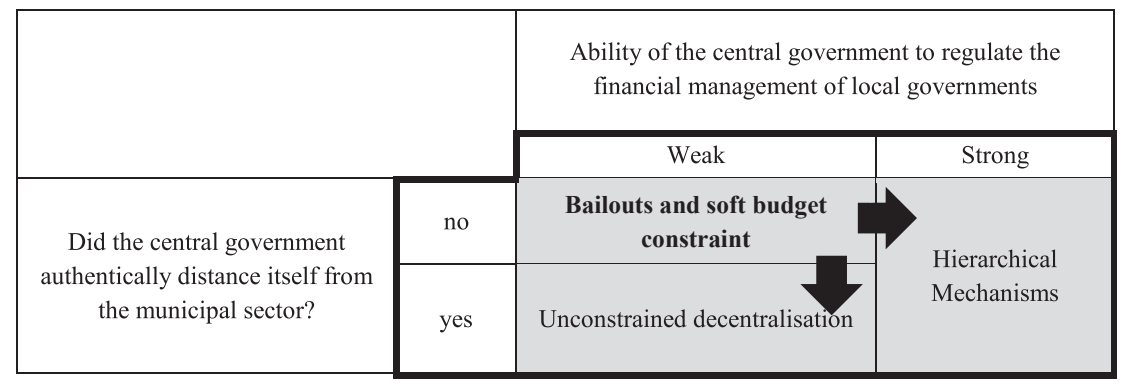

Fig. 1. Dimensions of intergovernmental relations ${ }^{2}$

Source: Rodden - Eskeland (2003).

${ }^{2}$ The figure of Rodden-Eskeland (2003) also includes one additional dimension (the financial strength of the central government), which is omitted here: we presented only the case when the central government is fiscally strong. Otherwise weakness in this manner would mean sovereignty at municipal level. 


\subsection{Establishment of fiscal discipline}

To strengthen the fiscal discipline, the central government may strengthen market mechanisms to enable them to control the financial management of local governments themselves. According to Kornai (1993), this requires the achievement of the following pillars: (1) customer: pay for the goods purchased; (2) debtor: perform your credit agreement and repay your debt; (3) taxpayer: pay your tax and (4) company/local government: cover your costs from your revenues. If financial trouble occurs, this approach may also entail abandoning certain local governments. With this, the central government may demonstrate that it will not assume liability for municipal debts. Although this may lead to bankruptcy, it may encourage the local governments and market operators to be cautious in the future.

Other institutions and laws can clarify ex ante what procedure is expected in the event of the insolvency of a local government. This goal is served by, e.g. setting clear rules for the settlement of bankruptcy and debts of local governments; these procedures take place independently of the central government, which may guarantee that market mechanisms will control the financial management of local governments in the long term. According to Ter-Minassian - Craig (1997), essential conditions for this are the free market and the fact that same or similar regulations should apply to the local governments as to other market operators. It is necessary, furthermore, to ensure the availability of the necessary information for debtor rating (in particular, on outstanding debts and the ability to repay debts) and that local governments have guarantees that support a responsible budgetary policy (own control mechanisms). Last but not the least, it is essential that market operators do not expect any bailout.

\subsection{Administrative strengthening of the budget constraint}

In order to strengthen the credibility and commitment of the central government, a number of administrative tools may be at its disposal in order to enable it to avoid overspending and concomitant excessive indebtedness. The use of these methods may make budget constraints harder; however, with this there is a risk that local governments will take a subordinate role. Rodden et al. (2003) classify and characterise the available means as follows:

- Prohibition of borrowing and central coordination of the allocation of external funds. Means for this may be the maximisation of municipal debt levels, the approval of loan applications or even the total centralisation of municipal borrowing. Its advantage is that the development of municipal debt will be brought into line with macroeconomic efforts and vulnerability will be reduced. However, with this, the central government may acquire excessive influence in the decisions taken by the local governments. In addition, with the central approval of borrowing, the local governments may think that responsibility now lies with the central government, so they may rightly expect help and a bailout in the event of financial trouble (Ter-Minassian Craig 1997). This may undermine the politically neutral efforts of the central government refusing any bailout in the future. In the view of Rodden et al. (2003), credit allocation and loan restriction mechanisms are often politicised and, therefore, do not work in practice. However, the restricted condition, i.e. making the conditions of borrowing more stringent, may significantly set back projects, because they may be financed only from current surplus or savings (see also Besfamille - Lockwood 2007). The financing needs of projects appearing concentrated in time may unfairly burden the generations that finance their implementation 
or, without credit, the projects are postponed. This may be offset if the central government provides development funds or implements local projects itself; however, this may infringe the competence and autonomy of the local governments (Dafflon 2010).

- Rule-based mechanisms may limit the purpose and extent of borrowing: e.g. long-term funds may finance only projects or if the indebtedness and the annual debt service may not exceed a certain level. This includes also budget regulations, e.g. no deficit may be planned in the budget. Such a widespread set of conditions is the 'golden rule', which allows debt financing: this increases the autonomy of the local governments, allows more projects and ensures a fair distribution of financing burdens between generations (pay-as-you-use). The golden rule requires that (1) current expenditure may be covered only from current revenue (no operating deficit is allowed); (2) projects may be financed from loans and (3) the debt service may be covered by current income (no erosion of assets and debt spiral). Since the golden rule does not limit the allowable rate of borrowing, it may become necessary to apply separate rules for the rate of absolute or relative indebtedness (Dafflon 2010).

- If the central government decides to proceed with a bailout instead of releasing the hands of local governments, it may set certain conditions (at the municipal or sectoral level) in order to eliminate the root cause of the financial trouble. This allows institutional reform and may confirm that no bailout will take place in the future; thus, market operators and decision-makers can see that a new era sets in in the relationship between the local governments and the central government. Dietrichson - Ellegard (2012) studied the short- and long-term effects of conditional bailouts carried out in connection with 36 local governments in Sweden between 2000 and 2004. It was found that financial assistance made subject to the fulfilment of conditions (cost reduction and operating budget balance) did not erode fiscal discipline, in fact, it even strengthened it. Based on the results, they also venture to propose that financial assistance made subject to conditions is more effective in strengthening fiscal discipline than the application of a hard(er) budget constraint. The Dutch model must also be mentioned (Allers 2014): in this case, the loss or debt of local governments is backed by the explicit guarantee of the central government: if necessary, local governments will be bailed out. Nevertheless, the number of bailouts per year is quite low (2-4 per year between 2001 and 2014, involving less than 1\% of the local governments). The main reason for this is, according to the author, that autonomy of the local government is significantly curtailed during the 3- or 4-years period of bailouts. The financial situation of local governments typically improves after bailouts.

We have seen that the establishment of fiscal discipline is a more sluggish process than using central administrative tools to control financial management and strengthen the budget constraint. On the other hand, as the corresponding literature points out, the latter may inflict serious wounds upon local autonomy. Conditional bailouts, however, may have a positive effect on the development of fiscal discipline in the long run.

\section{CONSOLIDATION AND THE NEW LOCAL GOVERNMENT SYSTEM}

The central government set to transform public administration in Hungary in 2011 at a great pace. This paper covers only the changes in the sectoral budget constraint and in the rules of financial management. It discusses the main features of the consolidation between 2011 and 2014 , then the new local government system is presented briefly. 


\subsection{Municipal debt assumption}

There is a broad consensus that the budget constraint of the local governments in Hungary has remained soft even after the regime change in 1990. Despite the steps taken to push market actors towards fiscal discipline in 1996 (e.g. enactment of a debt settlement procedure and introduction of a borrowing limit), the general perception among local governments and financing banks remained that the central government would not release the hands of local governments (Gál 2011). Fiscal discipline could not emerge, mainly due to a design failure of the institutions mentioned. First, the borrowing limits were ineffective and unenforceable (Homolya - Szigel 2008). Second, the debt settlement procedure had several institutional weaknesses (Bajnai et al. 2018; Gál 2011). Since 1996, less than a hundred bankruptcy procedures started, which is an extraordinarily low figure compared to the number of local governments (approx. 3,200 ). No procedure was launched against the larger local governments, as it requires too much sacrifice from all the parties concerned. ${ }^{3}$ On the one hand, only the mandatory tasks may be performed and no project may be launched during the procedure, which would have significant effects on the local economy and public services. On the other hand, the banks (being the largest creditors) typically did not see the guarantee that they would achieve more in a long procedure, involving many additional creditors, than in the bilateral negotiations. Since the debt settlement procedure is not compulsory to launch, a number of local governments could have already gone into latent bankruptcy; in their case, although the conditions for launching a debt settlement procedure exist, the procedure is still not initiated; in the worst case, a bailout must come - so went the thinking of both creditors and local governments (Homolya - Szigel 2008).

The weak institutional setting was further burdened by a number of independent things: ${ }^{4}$ the excessive and continuous decentralisation of public service tasks; flexible budget boundaries (erosion of assets, operations financed from long term loans) and internal indebtedness; bond issues becoming widespread; an attempt to make the conditions of borrowing more stringent in 2007; the possibility of borrowing in foreign currency and the foreign exchange credit boom; the municipal leaders' moral responsibility (and the fact that the leadership of the majority of important local governments was in the opposition between 2006 and 2010); the possibility of off-balance sheet indebtedness (e.g. PPP or sureties); and last but not least the continuous expansion drive.

As a result, an enormous debt pile was accumulated by the local governments in the period between 2006 and 2010, and their deficit also rose to a peak level at that time. In 2011, the central government with two-thirds majority initiated an unprecedentedly large bailout, which confirmed the preliminary expectations on SBC: all debts of all local governments were generally assumed in four phases. The process was completed by 2014. As expected, opinions were divided as to whether a bailout action of such a scale was warranted (HUF 1,337 billion in total). ${ }^{5}$ According to Lentner (2014) and Molnár - Hegedüs (2018), the debt assumption was inevitable

\footnotetext{
${ }^{3}$ The Hungarian case confirms Wildasin (1997) as only the small local governments (mostly villages) got under debt settlement (the smaller a local government, the harder the budget constraint). Later it will be shown that those who may have really needed help were the larger local governments; probably their expectations of a bailout were also higher.

${ }^{4}$ For a detailed explanation of the individual topics, see Vigvári 2009, 2010; Vasvári 2009, 2013b; Jankovics 2016; Schepp - Pitz 2016; Kornai 1980, 2014.
}

${ }^{5}$ See Kornai (2014) for the details of the bail-out. 
and crucial for the continuous and sustainable operation of the local governments. Jankovics (2016) and Horváth et al. (2014) argues that the general and full debt consolidation that took place in Hungary had not been preceded by serious financial problems at the sector level. Thus, in fact, this bailout can be considered a indirect transfer provided in a differentiated way, a indirect transfer from the local governments and their residents who had no debt or had run into debt below average. ${ }^{6}$ Kornai (2014) quantifies the extent of the 'gift', and also points out the signs of political clientelism. The importance of a 'sector level' indicator cannot be sufficiently stressed, because financial problems had arguably arisen among the local governments. Almost all county governments became heavily indebted and, what is more, a large proportion of their long-term debt had financed operating expenses (Vasvári 2013a). In this case, the central government also assumed trade creditors. Local governments could also accumulate debt in a foreign currency; and only transaction exchange losses resulted in an almost 15\% (HUF 182 billion) increase in debt at the end of 2010 (which can be considered an unexpected external financial shock). However, even then the weight of the outstanding debt of the local governments did not reach $5 \%$ of the GDP or $6 \%$ of government debt (the expenditure of the municipal sector amounted to approximately $12.8 \%$ of the GDP at that time); and as Kornai (2014) points out, $82.6 \%$ of this debt was accumulated by 150 local governments ( $4.7 \%$ of local governments). As mentioned earlier, the municipal deficit also reached a record level in 2010, which thus increased the government deficit by $25 \%$. However, cities with county rank and districts of Budapest, i.e. fewer than 50 local governments, are responsible for almost half of this deficit. In addition, it is worth evaluating the bailout process also in the current economic policy space. During the bailout, significant funds were withdrawn from the bank sector (e.g. transaction levy, bank tax). Although the proportion of non-performing loans owed by the local governments was only $2.1 \%$ in mid-2011 (Jankovics 2016), the repayment of a significant part of the municipal debt would have only begun after 2011 (Vasvári 2013b). Therefore, the issue of municipal debt could easily become subject to bargaining in the turbulent relationship between the banking system and the central government. This confirms that the central government offered the last phase of the bailout of the local governments first to the financing banks. In exchange for assuming the remaining debt, the creditor should have paid an amount corresponding to $7 \%$ of the debt part assumed to the state coffers. Although the idea was not implemented in the end, the concrete proposals to be put before the municipal councils were also drafted in some cases.

In the knowledge of the above, targeted assistance provided subject to conditions at the level of the individual local governments could seem to be justified. The decision-makers of the central government chose another path and, by cancelling municipal debt, also relieved the local governments from the responsibility.

\subsection{Financial cornerstones of the new local government system}

Simultaneously with assuming debts at the sector level, the central government was set to transform the local government system. Even the Fundamental Law contains significant changes in local self-governance. According to it, the law may make borrowing or other commitments by

\footnotetext{
${ }^{6}$ Although the central government provided a total of HUF 50 billion in aid through applications to the local governments that did not have any debt, but did not provide any compensation to those the indebtedness of which did not reach the average level and consequently sustained detriment.
} 
local governments subject to the conditions of the consent of the Government in order to maintain budgetary balance.

The foundations of the new local government system are set out in the supermajority law on the local governments of Hungary. A significant trend of centralisation can be observed in the division of tasks: county governments essentially no longer perform public service tasks, while such tasks have been withdrawn from local governments to a significant extent (e.g. education, health care). In addition, the financial latitude of the local governments has narrowed even further due to the introduction of a 'task financing system' (Sivák et al. 2013). As one of the most important changes, the Law declares that no externally financed operating deficit may be planned in budgets.

The new Act literally repeats the promise also included in the earlier Local Government Act, according to which 'the consequences of the loss-making financial management of the local government burden the same local government and the central budget is not responsible for its liabilities.'

In line with the authorisation granted in the Fundamental Law, the Economic Stability Act contains the rules for local government borrowing. It requires, above all, the fulfilment of certain convergence criteria for government budget deficit and the government debt indicator; in connection with the latter, since the government debt indicator exceeds the required $60 \%$ (74.5\% at the end of 2017), it requires to be reduced. Since municipal debt is a part of government debt, the latter requirement also provides a framework for the municipal borrowing. The most important change is that from 1 January 2012 the local governments may validly conclude transactions giving rise to a debt and may assume any surety or guarantee only with the prior consent of the central government. According to the Act, the central government consents to borrowing only if the following conditions are met jointly:

1. the transaction giving rise to a debt does not jeopardise the achievement of the general government debt ratio specified in the Central State Budget Act;

2. the transaction giving rise to a debt results in the establishment of a capacity required for performing the task of the local government specified by law, with the proviso that operating expenses are continuously covered;

3. it has introduced local business tax or at least one of the pecuniary taxes specified in the Local Tax Act or the communal taxes on private individuals; and

4. it is within the borrowing limit (generally the total payment obligation of the local government arising from a transaction may not exceed $50 \%$ of the local government's own revenues).

Rodden - Eskeland (2003) draw attention to the fact that local governments tend to avoid rule-based mechanisms. The amendments of the acts closed these back doors gradually. Such was the amendment of existing contracts (e.g. changing the term of loan or the terms of maturity or principal repayment grace period) or running into debt through municipally owned companies. Even contract amendments have become subject to authorisation by now. The growth of municipal debt through municipally owned companies was first limited by the assumption of sureties and guarantees by local governments, then from 2015 by making borrowing by $100 \%$ municipally owned companies subject to authorisation. This was also justified by the fact that according to the Ministry of Interior the growth of municipal debt shifted to entirely or partially municipally owned companies, where an outstanding debt of more than HUF 1,000 billion was accumulated. This is an amount of the same magnitude as that assumed by the central government from the local governments. 
All transactions giving rise to a debt, which are planned in the given year, have to be included in their by-laws on the budget and the central government has to be informed about it in advance. Then the request for the consent of the central government must be drawn up for each transaction during the year. The Government decides on approval on the basis of the joint proposal and recommendation of the Minister responsible for local governments and the Minister responsible for the state budget. The Government may also consent to part of the individual transactions or may even refuse them. In the light of the development goals, a decision may be made which contributes an amount lower than planned by the local government to the related transaction. Upon approval, the transaction giving rise to the debt or the suretyship agreement has to be concluded in the reference year.

Last but not the least, it is necessary to mention that the transformation of the local government sector did not affect the review of the municipal debt settlement procedure, so the rules for the municipal debt settlement procedure set in 1996 and largely unchanged ever since did not change during the reform. According to Bajnai et al. (2018), 559 local governments fulfiled the criteria of debt settlement procedure between 2012 and 2016, however, the procedure was initiated in 45 cases only (less than 10\%).

The new legislative environment continues not to deal with the issue of the internal indebtedness, i.e. depreciation not made up for. This is critical in the Hungarian local government system particularly because the local governments inherited substantial assets at the time of the regime change, for the maintenance/replacement of which no funds were provided (in 2016 the portfolio of municipal real estate was worth more than HUF 10,000 billion, about two-thirds of which was unalienable national asset). On the positive side, in addition to a cash flow-based approach, the local governments have performed accrual-based accounting since 2014, which, in addition to the fact that it may improve the evaluability of the economic processes of the local governments and the assessment of their creditworthiness for external financiers, also states depreciation as a cost.

\subsection{Evaluation}

In order to eliminate the phenomenon of SBCs and to strengthen the budget constraint, the central government chose a conditional bailout: in addition to a bailout, it hardened the budget constraint by administrative tools. ${ }^{7}$ In accordance with the recommendations in the literature, local governments may no longer plan operating deficit; however, this only applies to externally financed deficits, as operating deficits financed from asset disposals continue to be permitted. Task financing and the method of the calculation of central aid reduced the latitude of local governments, and last but not the least their interest to improve efficiency. As a rule, borrowing is to be approved by the central government or even the Government itself. Consequently, there may be local governments that forfeit the opportunity of borrowing notwithstanding that they have met the prescribed conditions.

This may significantly affect the level of municipal projects, and they may become defenceless to the intentions of the central government (Rodden 2003 and Dafflon 2010). The

\footnotetext{
${ }^{7}$ According to Horváth (2014), cause and effect are inverted: the incorrect suggestion of a crisis and the inevitability of intervention are to serve the 'smoothness' of the transformation of the sector. So, the withdrawal of the tasks appeared to be more justified with reference to the inevitability of crisis management. In fact, the centralisation efforts of the central government found their way easier between municipal decision-makers, without any resistance. As a result of all this, institution-based municipal autonomy, which was held responsible for everything, was eliminated.
} 
exclusive authorisation right of the government may also be a problem: since the Government and its administration are not prepared to assess credit risks, they may reject good projects in the absence of knowledge and information, while they may authorise projects that are not financially justifiable. With this, the Government may assume excessive responsibility (Sivák et al. 2013); at the same time, the authorisation of the Government can also be interpreted as a kind of implicit guarantee. This is further reinforced by the communication factor that the position taken by the central government, which refuses bailout, is identical, word for word, with its previous promise - which it obviously failed to honour once.

The strict control presented above is further supported by the facelifted borrowing criteria, which now mostly satisfy the conditions of the golden rule. The new version of the calculated borrowing limit also shows development compared to its predecessor in several points (e.g. it has to be met throughout the loan term, not only in the year of borrowing). It is a positive feature that the new regulations deal with the issue of off-balance sheet indebtedness and the increasing indebtedness of the municipally owned companies. Consequently, running into debt may also be put on a more sustainable path, however, the borrowing criteria along with the central approval mechanism represent a - perhaps unnecessary - double defence line to avoid unleashed borrowing.

Due to the above measurements, the financial management of local governments has consolidated in the new legislative environment (Fig. 2). Between 2013 and 2016, reflecting the operation of the new local government system, the budgetary expenditures dropped to about two-thirds of the 2010 level, while the outstanding debt virtually disappeared by 2014 as a result of debt consolidation and shows only a slight increase. The positive news is that budgets are also consolidated: after 2011 they became balanced.

The central government chose to use administrative mechanisms to control the financial management of local governments and avoid any negative effects of the bailout. To this end, it implemented new institutions and processes. The former institutional setting was partly updated accordingly (borrowing criteria), however, these updates seem weightless in the new system. A system restricting the latitude of local governments (and thus their autonomy) by administrative means has been established; the budget constraint is seemingly hard, but may carry the possibility of a future bailout. No significant steps have been taken towards fiscal discipline based on

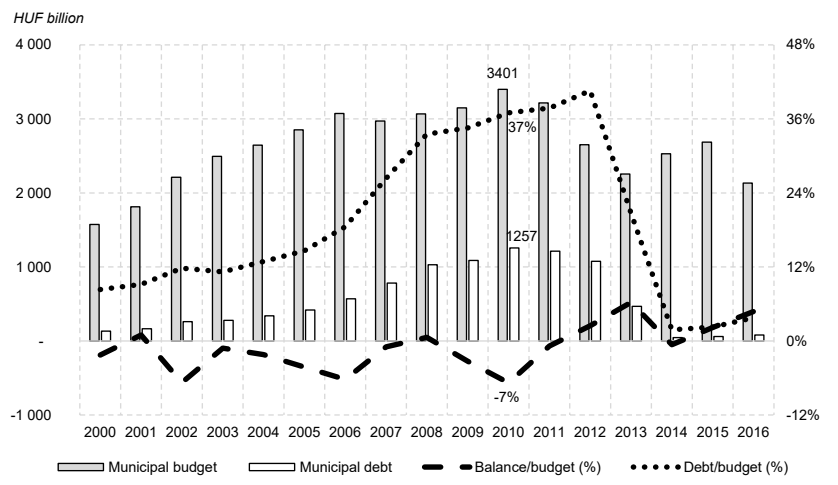

Fig. 2. The budget, debt and deficit of Hungarian local governments, 2000-2016

Source: Based on figures from the HCSO and the National Bank of Hungary. 
self-restriction or the restrictive power of the market (e.g. review of the debt settlement procedure), except for the introduction of accrual-based accounting.

\section{HYPOTHESES AND THE APPLIED METHODOLOGY}

The previous section introduced the new local government system - especially from the financial management aspect, while the first section reviewed the concept of SBC. In this section, we formulate two hypotheses on the consequences of the changes in the local government.

Rodden et al. (2003), Besfamille - Lockwood (2007) and Dafflon (2010) conclude that due to the increase of administrative controls over the municipal financial management, the level of municipal projects could drop. Thus, the second hypothesis is that the administrative strengthening of the budget constraint has a negative effect on municipal projects $(\mathrm{H} 1)$.

Rodden et al. (2003) also point out that the credit allocation and loan restriction mechanisms driven by the central government are often politicised. Kornai (2014) verified that the debt assumption of the local governments clearly showed political patterns. In the second hypothesis we assume when borrowing is authorised, patterns may appear, showing that political sympathy plays a role in the individual decisions (H2).

For the verification we used simple, descriptive statistical and illustrative tools, and for the first hypotheses I examined the aggregate datasets of the local governments, mainly from the Hungarian Central Statistical Office (HCSO). For the second hypothesis I analysed all decisions on borrowing by the local governments issued between 2012 and 2017 and arranged them in a database. A total of 50 government resolutions included 716 decisions to examine. To check political affiliation, it was assigned to local governments in the database whether the mayor had been nominated by the ruling parties or an opposition party or entered the elections as an independent candidate of another party in the given government cycle based on the data of the National Election Office. Later, I expanded the analysis to explore the reasons for rejection, as they are not indicated in the government resolutions: it is attempted to verify whether the financial situation of the local governments and the rejection correlate, or not. For this, we analysed the fulfilment of the objective borrowing criteria (see previous section) of each transaction and the local governments concerned. These criteria are as follows:

- the transaction is related to the performance of a statutory task (according to the government resolutions),

- the levied taxes (based on Tax online database),

- the existence of the operating capacities, which was assumed in the case of local governments where the operating budget had been balanced, and

- the compliance with the debt rule, where the debt service of the new transaction was compared to the borrowing limit of the local governments concerned; latter was calculated on the basis of the statutory revenues and the debt service in the given year (without taking into account the charges relating to the new transaction).

The latter two criteria are verified through analysing the corresponding annual budget reports of the local governments, which was provided by the Hungarian State Treasury.

Fig. 3 illustrates the connection between the hypotheses, the applied methodology and the corresponding literature. 
Framework: Central government have increased control over the financial management of the Hungarian local governments

Corresponding literature

Dafflon (2010)
Besfamille and
Lockwood (2007)

Possible consequences

The level of municipal projects could drop.

The borrowing decisions

could be politically biased.
Hypothesis

H1: The administrative strengthening
of the budget constraint has a
negative effect on municipal projects.

Methodology

$\rightarrow \begin{gathered}\text { Examination the aggregate } \\ \text { datasets of the local } \\ \text { governments by the HCSO. }\end{gathered}$

Fig. 3. The connection between hypotheses, applied methodology and the corresponding literature Source: Own compilation. 


\section{THE NEW LOCAL GOVERNMENT SYSTEM IN PRACTICE}

This section will analyse the practical experiences of the new legislative environment through verifying the two hypotheses formulated in the previous section.

H1: The administrative strengthening of the budget constraint has a negative effect on municipal projects.

According to Vigvári (2011), fiscal discipline and the borrowing activities of the local governments are of special significance because the greater part of the public projects are implemented by the local governments. This is also justified by the principle of subsidiarity. In the majority of the EU-27 countries, including Hungary, the share of local governments in public projects was close to or over $50 \%$. The latter is well illustrated in Fig. 4 . However, the trend seen between 2000 and 2010 was broken: the weight of the local governments in public projects have dropped to a level lower by orders of magnitude from 2011, due to the significant increase of government projects. In 2016, the local governments implemented less than a quarter of public projects. However, also the schedule of drawing down aid from the European Union could have significant impact on the level of investments. In this respect, it can be said that between 2010 and 2015, the amounts drawn down increased by $75 \%$, but a major (45\%) decline took place in the last year. As a result, the total amount drawn down fell to the 2010 level. This means that the setback in municipal projects was caused between 2010 and 2016 by a decrease in projects financed not from EU aid but from the local government's own funds and credit sources. ${ }^{8}$

According to Rodden et al. (2003) and Dafflon (2010), with the decline in municipal projects, the influence of the central government on local projects may increase. This trend is confirmed in the example of Hungary: the central government has implemented and still implements to date a number of development programmes satisfying local interests. ${ }^{9}$ This has three main consequences: firstly, the autonomy of the local governments obviously decreases and they are at the mercy of central decisions. ${ }^{10}$ Secondly, there is a possibility that the central government makes its decisions on the basis of political sympathy or lobbying, which places the municipalities left out at a disadvantage. Thirdly, these projects do not require that the operating expenses of the capacities implemented with the project be ensured (which is incidentally required by the central government in projects implemented through borrowing by local governments). This can lead to a conflict as to who should operate the new facilities established or from what funds their condition will be preserved, as it already have happened in Hungary.

On the basis of the above, hypothesis $\mathrm{H} 1$ is accepted: the number of municipal projects significantly decreased; at the same time, we are witnessing a significant increase in the role of

\footnotetext{
${ }^{8}$ Vasvári (2013a) shows that EU financing did not dominate yet in the financing of municipal projects until 2010.

${ }^{9}$ For example the Modern Cities Programme, under which the central government entered into an agreement with the 23 largest cities in the provinces for the implementation of development objectives in a total value of HUF 3,388 billion.

${ }^{10}$ For example the Mayor of Szombathely (a city with county rank and a population of 78 thousand) declared at the inauguration ceremony of the football stadium built in the city as a government project that they had obviously received this gift, 'because they had behaved properly'. We can recall Kornai's (1980) words: 'The need for projects is not limited by fear from loss or failure. (...) Projects are gifts to the applicants.'
} 


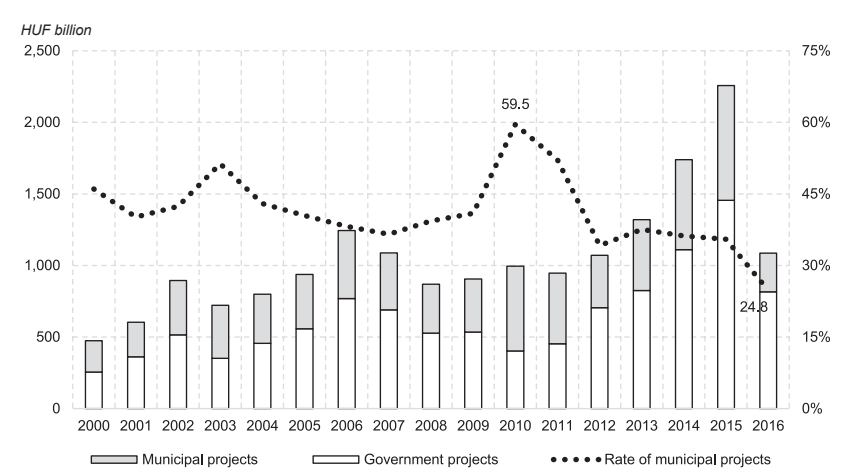

Fig. 4. Accumulation of gross fixed assets by the central government and local governments in Hungary, 2000-2016

Source: Based on figures from the HCSO.

the central government in local projects, which may cause the decline of municipal autonomy and discrimination against certain local governments.

$\mathrm{H} 2$ : When borrowing is authorised, patterns may appear, showing that political sympathy plays a role in the individual decisions.

First, the distribution of applications for the central approval of borrowing is examined (Table 1). Based on this, it can be said that $47.3 \%$ of the applications were submitted by the local governments led by mayors affiliated with the governing party; in respect of the loan amounts, this represents a weight over $85.6 \% .4 .8 \%$ of the applications can be associated with municipalities affiliated with the opposition, which is considerably lower than the figure observed for the ruling party but is higher than the proportion of the local governments led by them (1.6\%). $47.9 \%$ of the applications were submitted by independent local governments, but in terms of value this corresponds to only $10 \%$. The reason for this is that the national political parties enter candidates typically in larger municipalities, the budget and borrowing capacity are much larger than those of smaller villages typically led by the independent mayors.

Table 1 essentially shows demand for municipal loans on the basis of political affiliation. The extent of the demand for loans before the reform and consolidation is simply estimated with the outstanding to be consolidated. According to the order shown in Table 1, this is 71,7 and 22\%, respectively (Kornai 2014). Consequently, it can be established that the intention of the independent-led local governments to borrow has declined significantly. This may mean a decline in borrowing by smaller towns and villages, which may be caused by these local governments not fulfiling the borrowing rules, or these smaller local governments are not found creditworthy as a result of the more cautious lending policy of banks. The significant administrative burden of the procedure may be also deterrent.

Examining the decisions (Table 2), it can be said that while the central government approves $89.1 \%$ of the applications, it approves less than $70 \%$ of the applications associated with opposition parties. The Cramer coefficient (0.17), however, anticipates weak relationship between the political affiliation and the approval rate. The distribution of the volume approved shows greater 
Table 1. National distribution of borrowing applications and the status of mayors by political affiliation

\begin{tabular}{|c|c|c|c|c|c|c|}
\hline \multirow[b]{2}{*}{ Political affiliation } & \multicolumn{2}{|c|}{ Distribution of mayors (2014) } & \multicolumn{2}{|c|}{$\begin{array}{c}\text { Distribution of the } \\
\text { number of } \\
\text { applications }\end{array}$} & \multicolumn{2}{|c|}{$\begin{array}{l}\text { Distribution of the } \\
\text { amount stated in the } \\
\text { application }\end{array}$} \\
\hline & Local government & $\%$ & Pcs & $\%$ & HUF billion & $\%$ \\
\hline Governing party & 627 & 19.8 & 339 & 47.3 & 341 & 85.6 \\
\hline Opposition & 51 & 1.6 & 34 & 4.8 & 17.5 & 4.4 \\
\hline Independent/0ther & 2,485 & 78.6 & 343 & 47.9 & 40 & 10.0 \\
\hline Total & 3,163 & 100.0 & 716 & 100.0 & 398.5 & 100.0 \\
\hline
\end{tabular}

Source: Based on figures from government resolutions and the National Election Office.

differences: in this respect, local governments affiliated with opposition parties received approval only for less than half of the loan amounts they wanted to borrow. This is also confirmed by the corresponding Cramer coefficient (0.41), based on which moderate relationship is assumed.

The reason for this, however, is not necessarily a political bias: it is conceivable that the opposition local governments are in a fundamentally worse budgetary situation (e.g. this can also justify the opposition leadership), and the objective conditions are not met during borrowing. Since the reason for rejection is not indicated in the government resolutions, we attempted to verify if the budgetary situation correlates with the rejection of the applications. The analysis is based on the objective borrowing criteria set by the Law:

- the transaction is related to the performance of a statutory task;

- the local government has imposed the local taxes established by law;

- the continuous payment for operating expenditure is ensured; and

- the municipal debt rule is fulfiled.

Table 2. Approval rate of borrowing applications by political affiliation

\begin{tabular}{|l|c|c|c|c|c|c|}
\hline \multirow{2}{*}{ Political affiliation } & \multicolumn{4}{|c|}{ Number of applications } & \multicolumn{3}{c|}{$\begin{array}{c}\text { Amount stated in the application (HUF } \\
\text { billion) }\end{array}$} \\
\cline { 2 - 7 } & Approved & Rejected & Approval rate, \% & Approved & Rejected & Approval rate, \% \\
\hline Governing party & 314 & 25 & 92.6 & 324.8 & 16.2 & 95.2 \\
\hline Opposition & 23 & 11 & 67.6 & 7.9 & 9.6 & 45.0 \\
\hline Independent/Other & 301 & 42 & 87.8 & 28.8 & 11.2 & 71.9 \\
\hline Total & 638 & 78 & 89.1 & 361.5 & 37.0 & 90.7 \\
\hline
\end{tabular}

Source: Based on figures from government resolutions and the National Election Office. 
Table 3. Fulfilment of the conditions for operating margin and the debt rule in borrowing applications by political affiliation

\begin{tabular}{|l|c|c|c|c|c|c|}
\hline \multirow{2}{*}{$\begin{array}{l}\text { Political } \\
\text { affiliation }\end{array}$} & \multicolumn{3}{|c|}{ Operating balance } & \multicolumn{3}{c|}{ Fulfilment of debt rule } \\
\cline { 2 - 7 } & Deficit & Surplus & $\begin{array}{c}\text { Proportion of those } \\
\text { with deficit, \% }\end{array}$ & $\begin{array}{c}\text { Not } \\
\text { fulfiled }\end{array}$ & Fulfiled & $\begin{array}{c}\text { Proportion of those not } \\
\text { fulfiling the rule, \% }\end{array}$ \\
\hline $\begin{array}{c}\text { Governing } \\
\text { party }\end{array}$ & 65 & 274 & 19.2 & 75 & 264 & 22.1 \\
\hline Opposition & 1 & 33 & 2.9 & 4 & 30 & 11.8 \\
\hline $\begin{array}{l}\text { Independent/ } \\
\text { Other }\end{array}$ & 94 & 249 & 27.4 & 67 & 276 & 19.5 \\
\hline Total & 160 & 556 & 22.3 & 146 & 570 & 20.4 \\
\hline
\end{tabular}

Source: Based on figures from government resolutions, the Hungarian State Treasury and the National Election Office.

According to the analysis, it can be concluded that all transactions were related to the tasks of local governments and the local governments did impose the taxes required for borrowing. The results on the latter two criteria are shown in Table 3. It can be established that the transactions associated with the opposition perform better according to both considerations: there was an operating deficit in one case, while the debt rule was not fulfiled in four cases. The worse-thanaverage situation of independent local governments, as previously noted, may be caused by a smaller municipality size, which may also play a role in access to credit sources. Based on this, it can be assumed that the refusal of borrowing by local governments affiliated with the opposition is not affected by the financial situation of the local governments.

Consequently, hypothesis $\mathrm{H} 2$ is accepted: signs of political clientelism can be found in central government approval of borrowing between 2012 and 2017. In addition, it was shown that access to credit sources by smaller municipalities was limited in the new legislative environment.

\section{CONCLUSIONS}

One of the biggest challenges of fiscal decentralization is the handling of the SBC. With the help of the literature, it was pointed out that during the hardening of the budget constraint two main approaches could be applied: the restriction of financial management and access to external funds by administrative tools or the strengthening of the fiscal discipline of local governments. In the case of the former, the vulnerability of the central government may decrease and the financial management of local governments may become consolidated in the short term; at the same time, it may result in a significant curtailment of municipal autonomy. The establishment of fiscal discipline is a longer process because it requires a change in the behaviour and deeply ingrained expectations of market operators. 
The bailout process of the local governments in Hungary between 2011 and 2014 was briefly reviewed. It is argued that a, general and full bailout was not justified due to the concentrated nature of the problems. At the same time, it may provide a special interpretation of the events if they are evaluated in the relationship between the financial sector and the central government. Simultaneously with the bailout, the central government decided to strengthen its control over the local governments, neglecting fiscal discipline. A few positive changes can be observed in the new statutory system (e.g. restrictions on operating balance, new borrowing limit, accrual-based accounting). However, the approval of loans by the central government (in fact, directly by the Government) projects a substantial reduction of access to external funds, which may also affect the level of projects, assuming, at the same time, an implicit guarantee for approved loans. Moreover, the central government kept several rules and processes from the previous municipal system which may seem unnecessary under the present conditions.

Following the reform, the financial management of the local governments became consolidated, the fulfilment of the relevant convergence criteria was not jeopardised by the financial management of local governments and the vulnerability of the central government decreased. At the same time, there was a significant setback in municipal projects and projects promoted by the central government and serving local interests try to fill this void, which may inflict significant wounds on municipal autonomy. Furthermore, the new system significantly limits access to external funds, mainly by smaller municipalities, which is aggravated by the fact that loan approval applications are not free from political affiliation. It is concluded that although the strict rules are the same for all local governments, the central government employs specific administrative tools to show favour to some settlements according to its (political) interests. Accordingly, the institution of political clientelism that is a feature of the SBC is still alive and well in the era of strict central controls and hard budget constraint. By giving up a significant part of their autonomy, local authorities paid a too high price for getting rid of their debt burdens. Nevertheless, the SBC remained in place: its textbook example at hand is the city of Pécs (the fourth largest city after Budapest in Hungary with a population of 145,000), which already requested bailout in the middle of 2017. However, this time the central government picked up the gauntlet and set strict conditions for another bailout. This deterrent example may represent a shift towards establishing fiscal discipline for the local governments, in line with the findings of Dietrichson - Ellegard (2012) and Allers (2014).

Based on these findings, it is recommended to strengthen the fiscal discipline in order to dismantle the SBC. First, the appropriate institutions have to be put in place (e.g. review of the debt settlement procedure). Afterwards, the hierarchical mechanisms have to be gradually eliminated. Together with the restoration of the autonomy of local communities, it is necessary to return local projects to the local governments.

\section{ACKNOWLEDGEMENTS}

The research was financed by the Higher Education Institutional Excellence Programme of the Ministry of Human Capacities in Hungary, within the framework of the 4th thematic programme 'Enhancing the Role of Domestic Companies in the Reindustrialization of Hungary' of the University of Pécs (Grant No.: 20765-3/2018/FEKUTSTRAT). 


\section{REFERENCES}

Allers, M. A. (2014): The Dutch Local Government Bailout Puzzle. Public Administration, 93(2): 451-470. Bajnai, Zs. - Németh, I. - Pomázi, O. - Szudi, F. (2018): Eléri-e célját az önkormányzati adósságrendezés? (Does the Municipal Debt Settlement Procedure Reach its Goals?) Budapest: State Audit Office of Hungary.

Besfamille, M. - Lockwood, B. (2007): Bailouts in Federations: Is a Hard Budget Constraint Always Best? International Economic Review, 49(2): 577-593.

Dafflon, R. (2010): Local Debt: From Budget Responsibility to Fiscal Discipline. IEB 6th Symposium on Fiscal Federalism, Barcelona, 14-15 June 2010.

Dietrichson, J. - Ellegard, L. M. (2012): Assist or Desist? Conditional Bailouts and Fiscal Discipline in Local Governments. Working Paper, No. 2012:24, Sweden: Lund University.

Fink, A. - Stratmann, T. (2009): Institutionalized Bailouts and Fiscal Policy: The Consequences of Soft Budget Constraints. CESifo Working Paper, No 2827. Munich: Center for Economic Studies.

Gál, E. (2011): Is it Necessary to Regulate Local Governments' Borrowing? Public Finance Quarterly, 56(1): 125-146.

Goodspeed, T. J. (2002): Bailouts in a Federation. International Tax and Public Finance, 9(4): 409-421.

Homolya, D. - Szigel, G. (2008): Önkormányzati hitelezés - kockázatok és banki viselkedés (Lending to Local Governments - Risks and the Behaviour of Banks). MNB Szemle, 09: 20-29.

Horváth, M. T. (2014): Sarkalatos átalakulások - a kétharmados törvények változásai 2010-2014: Az önkormányzatokra vonatkozó szabályozás átalakulása (Cardinal Transformations - Changes in Laws that can be Modified by a Two-thirds Majority, 2010-2014: Transformation of the Regulations Applicable to Local Governments). MTA Law Working Papers, No. 2014/04. Budapest: Social Sciences Research Institute of the Hungarian Academy of Sciences.

Horváth, M. T. - Péteri, G. - Vécsei, P. (2014): A helyi forrásszabályozási rendszer magyarországi példája, 1990-2012 (A Hungarian Example of the Local Funds Regulation System, 1990-2012). Közgazdasági Szemle, 61(2): 21-147.

Inman, R. P. (2003): Transfers and Bailouts: Enforcing Local Fiscal Discipline with Lessons from U.S. Federalism. In: Fiscal Decentralization and the Challenge of Hard Budget Constraints. The MIT Press, pp. 35-83. Jankovics, L. (2016): Local Government Finances in Hungary: From the Culprit of Fiscal Slippages to a Source of Stability? Society and Economy, 38(4): 455-478.

Kornai, J. (1980): Economics of Shortage. Amsterdam: North-Holland.

Kornai, J. (1993): The Evolution of Financial Discipline under the Postsocialist System. KYKLOS, 46(3): 315-336.

Kornai, J. - Maskin, E. - Roland, G. (2003): Understanding the Soft Budget Constraint. Journal of Economic Literature, 41(4): 1095-1136.

Kornai, J. (2014): The Soft Budget Constraint - An Introductory Study to Volume IV of the Life's Work Series. Acta Oeconomica, 64(1): 25-79.

Lentner, Cs. (2014): The Debt Consolidation of Hungarian Local Governments. Public Finance Quarterly, 59(3): 310-325.

Molnár, P. - Hegedüs, Sz. (2018): Municipal Debt Consolidation in Hungary (2011-2014) in an Asset Management Approach. Civic Review, 14(Special Issue): 81-92.

Robinson, J. A. - Torvik, R. (2009): A Political Economy Theory of the Soft Budget Constraint. European Economic Review, 53(7): 786-798. 
Rodden, J. - Eskeland, G. S. - Litvack, J. (2003): Introduction and Overview. In: Fiscal Decentralization and the Challenge of Hard Budget Constraints. The MIT Press, pp. 3-31.

Rodden, J. - Eskeland, G. S. (2003): Lessons and Conclusions. In: Fiscal Decentralization and the Challenge of Hard Budget Constraints. The MIT Press, pp. 431-465.

Schepp, Z. - Pitz, M. (2016): Foreign Currency Borrowing in Hungary: The Pricing Behaviour of Banks. In: Boubaker, S. - Buchanan, B. G. - Nguyen, D. K. (eds): Risk Management in Emerging Markets: Issues, Framework and Modeling. Emerald Group Publishing, pp. 469-504.

Sivák, J. - Szemlér, T. - Vigvári, A. (2013): A magyar államháztartás és az Európai Unió közpénzügyei (The Hungarian State Budget and Public Finances in the European Union). Budapest: Complex Kiadó.

Ter-Minassian, T. - Craig, J. (1997): Control of Subnational Government Borrowing. In: Fiscal Federalism in Theory and Practice (Section 7). IMF, pp. 156-172.

Vasvári, T. (2009): Az önkormányzatok kötvényfinanszírozása és a felmerülö kockázatok kezelése (Bond Financing of Local Governments and Management of the Arising Risks). Manuscript. University of Pécs.

Vasvári, T. (2013a): Önkormányzati beruházások finanszírozása az európai uniós támogatások tükrében (Financing of Municipal Projects in the Light of European Union Aid). Statisztikai Szemle, 91(2): 155-184.

Vasvári, T. (2013b): The Financial Management of Local Governments in 2011 in Light of the Crowdingout Effect of their Debt Service. Public Finance Quarterly, 58(3): 307-333.

Vigvári, A. (2009): Pénzügyi kockázatok az önkormányzati rendszerben (Financial Risks in the Local Government System). Budapest: Research Institute of the State Audit Office.

Vigvári, A. (2010): Is the Conflict Container Full? Problems of Fiscal Sustainability at the Local Government Level in Hungary. Acta Oeconomica, 60(1): 49-77.

Vigvári, A. (2011): Önkormányzati pénzügyek - hazai kihívások és nemzetközi példák (Municipal Finances Challenges in Hungary and International Examples). Budapest: Research Institute of the State Audit Office.

Wildasin, D. E. (1997): Externalities and Bailouts: Hard and Soft Budget Constraints in Intergovernmental Fiscal Relations. Policy Research Working Paper, No. 1843. The World Bank.

\section{DATA SERIES AND DATABASES}

Tax Online (www.ado.hu): Helyi adók adatbázisai (2013-2017) (Local tax databases (20132017)).

Hungarian Central Statistical Office (HCSO): A kormányzati szektor fóbb adatai a nemzeti számlák módszertana szerint 1996-2016 (Main data of the government sector according to the methodology of national accounts, 1996-2016).

National Bank of Hungary: A nemzetgazdaság pénzügyi számlái (Financial accounts of the national economy).

Hungarian State Treasury: Önkormányzatok éves költségvetési beszámolói 2007-2016 (Annual budget reports of local governments, 2007-2016). 
National Election Office: 2010. és 2014. évi önkormányzati választások eredményei (Results of the 2010 and 2014 municipal elections); the results of the 2014 municipal elections, arranged into a database, are courtesy of GeoX Kft.

Open Access. This is an open-access article distributed under the terms of the Creative Commons Attribution 4.0 International License (https://creativecommons.org/licenses/by/4.0/), which permits unrestricted use, distribution, and reproduction in any medium, provided the original author and source are credited, a link to the CC License is provided, and changes - if any - are indicated. (SID_1) 